\title{
ANALISIS PERSEPSI MUZAKI TERHADAP PREFERENSI DAN KEPUTUSAN MEMILIH LEMBAGA AMIL ZAKAT (STUDI KASUS DI KOTA MEDAN DAN SEKITARNYA)
}

\author{
Satria Darma \\ Mahasiswa Program Pascasarjana UIN Medan \\ muhammadsatria@gmail.com \\ Saparuddin Siregar \\ Dosen Program Pascasarjana UIN Medan \\ Mustafa Kamal Rokan \\ Dosen Program Pascasarjana UIN Medan
}

\section{j-EBBIS}

Jurnal Ekonomi dan Bisnis

Islam

Volume : 2

Nomor: 1

Halaman 1-24

Langsa, April 2017

ISSN : 2502-1397

E-ISSN : $2540-8100$

\section{Abstract}

The objective of this research is; firstly to analyze the impact of the perceptions, that the perception of service, promotions and location of the Muzaki's preferences, then to analyze the impact of the preferences towards Muzaki's decision, and finally to analyze the impact of the perceptions of service, promotions, location and preferences of Muzaki's decision in choosing LAZ. This research is a quantitative research using path analysis method through LISREL 8.80 assisted by MSI (Method of Succesive Interval) and SPSS 16.0 application tool to test the feasibility of the data. The results showed that perception of service very influential to preference compared with promotion and location.

And Preference has a significant influence on decisions rather than perceptions of service, promotion and location. This study recommends Amil Zakat Institute to be able to improve the service because it is a matter of great concern and felt directly by muzaki and become preference for muzaki in determining its decision in choosing Amil Zakat Institution.

Keywords: Decision, Muzaki Preferences, Perceptions of Service, Promotion, Location.

\section{PENDAHULUAN}

Banyak pilihan bagi muzaki dalam memilih membayarkan zakatnya melaui LAZ. Keputusan muzaki memilih wadah, tempat, lembaga maupun badan dalam membayarkan zakatnya adalah hak prerogatif dari masing-masing muzaki sendiri. Tentunya keputusan muzaki dalam menyalurkan zakatnya dan memilih suatu Lembaga Amil Zakat atau bisa disingkat dengan LAZ, membawa kemanfaatan bagi LAZ yang menjadi tempat bagi muzaki mempercayakan penyaluran zakatnya dengan harapan bahwa LAZ dapat amanah dalam proses distribusi nantinya. Karena salah satu tugas dan kewajiban LAZ adalah harus amanah dalam pengelolaan zakat. 
Di akhir tahun 2015 tercatat ada 2.173 (dua ribu seratus tujuh puluh tiga) muzaki yang telah membayarkan zakatnya pada LAZ Dompet Dhuafa Waspada Sumatera Utara, dengan berbagai macam latar belakang yang berbeda (Juliana: 2016). Jumlah tersebut cukup banyak melihat dari latar belakang lembaga tersebut adalah lembaga non pemerintah. Begitu juga ketika peneliti mendatangi LAZ Rumah Zakat yang hampir setiap bulannya di tahun 2016 ini terhitung kisaran 150 sampai dengan 200 muzaki yang membayarkan zakatnya melalui lembaga ini (Mila Nova: 2016). Di samping 2 (dua) lembaga non pemerintah tersebut, ada juga LAZ IZI (Inisiatif Zakat Indonesia) yang baru beroperasi pada tanggal 1 Januari 2016 yang diusianya yang begitu muda memiliki rata-rata muzaki perbulannya sekitar 30 sampai dengan 35 muzaki khusus untuk zakat profesi (Muhammad Iqbal:2016). Jumlah muzaki kesemuanya itu belum termasuk muzaki yang membayarkan zakatnya pada LAZ lainnya.

LAZ nasional resmi yang terdaftar pada Direktoral Jendral Pajak RI yang memiliki kantor perwakilan di Sumatera Utara ada 5 LAZ antara lain; LAZ Dompet Dhuafa/ DD Waspada,LAZ Rumah Zakat, LAZ IZI (merupakan pembelahan LAZ PKPU), LAZ BMH (Baitul Mal Hidayatullah), LAZIS Muhammadiyah (http://www.pajak.go.id).Selain dari 5 (lima)Lembaga Amil Zakat tersebut di Sumatera Utara dan di Medan antara lain ada; (Baznas Sumut:2016) LAZ Al-Hijrah,LAZ Nurul Hayat,LAZ Ulil Albab,LAZ PZU,dll.

Dalam mengambil keputusan memilih tempat, wadah, lembaga, badan atau bisa dikatakan Organisasi Pengelola Zakat (OPZ) tentu dan pastinya muzaki mempunyai banyak pilihan sebagaimana telah diuraikan di atas. Muzaki tentunya dapat memilih dari salah satu LAZ atau bahkan muzaki bisa menyalurkan zakatnya melalui BAZ (Badan Amil Zakat). Organisasi Pengelola Zakat BAZ yang kalau sekarang disebut BAZNAS (Badan Amil Zakat Nasional), ada BAZNAS Pusat untuk tingkat pengelolaan di Pusat/ secara Nasional, ada BAZNAS Provinsi untuk pengelolaan zakat ditingkat provinsi, BAZNAS Kabupaten/Kota untuk pengelolaan zakat ditingtkat Kabupaten/Kota, atau bahkan ada juga UPZ (Unit Pengumpul Zakat) yang dibentuk untuk membantu BAZNAS ( UU No 23 Tahun 2011).

Terkadang juga masih banyak muzaki yang bahkan memilih untuk menyalurkan zakatnya langsung kepada mustahiq tanpa melalui amil zakat yang telah ditunjuk dan diresmikan oleh pemerintah. Hal ini senada seperti yang disampaikan oleh mantan Menteri Agama RI Bapak Suryadharma Ali, bahwa: (Antara News: 2013) kebanyakan orang mampu di Indonesia itu lebih suka menyalurkan zakatnya secara langsung kepada para penerimanya (mustahiq). Alasannya, mereka belum percaya kepada Baznas.

Dimana saat ini realisasi zakat nasional masih jauh dari target. Tentunya target zakat nasional seyogyanya ingin merealisasikan dan memaksimalkan potensi zakat yang 
ada. Dilansir dari beberap rujukan yang ada bahwa, potensi zakat secara nasional ditaksir mencapai Rp 217 triliun setiap tahun. Angka itu dilihat berdasarkan produk domestik bruto (PDB). Ketika PDB naik, maka potensi zakat juga bergerak. Jadi, itu didasarkan pada PDB tahun 2010. Padahal setiap tahun PDB bergerak naik. Kalau memperhitungkan pertumbuhan PDB tahun-tahun sesudahnya, maka tahun 2016 ini potensi zakat berubah menjadi sekitar Rp 274 triliun (Republika:2016). Diekstrapolasikan dengan pertimbangan pertumbuhan ekonomi nasional tahun-tahun sesudahnya maka potensi tahun 2015 sudah lebih dari Rp 280 triliun. Padahal zakat, infak dan sedekah nasional yang bisa dihimpun pada tahun 2015 diperkirakan baru Rp. 4 triliun atau kurang dari 1,4\% potensinya (Arsip Baznas Sumut : 2016).

Oleh karena perlu adanya semangat bersama dalam memaksimalkan potensi zakat, termasuk dengan memberikan izin kepada lembaga-lembaga zakat yang dibentuk oleh masyarakat sesuai amanat Undang-Undang No. 23 Tahun 2011 Tentang Pengelolaan Zakat. Dengan bantuan LAZ yang kuantitas dan kualitasnya maksimal tentu juga akan memaksimalkan mengejar ketertinggalan target yang ada. Sehingga jika LAZ maupun jaringan outlet pembayaran zakat semakin banyak maka tentu akan meningkatkan penerimaan zakat. Akan terjadi juga kompetisi antar LAZ dalam meningkatkan pelayanan serta memberikan daya tarik bagi Muzaki maupun calon Muzaki untuk membayarkan zakatnya.

Beberapa LAZ mempunyai inovasi dan kreatifitas dalam menarik minat Muzaki untuk menjadi donatur. Sampai saat sekarang di tahun 2016 ini misalnya LAZ IZI memiliki 5 program baru yaitu Izi to success, Izi to smart, Izi to fit, Izi to iman, dan Izi to help (https://izi.or.id). Begitu juga LAZ Rumah Zakatdengan program Senyum Senyum Juara, Senyum Sehat, Senyum Mandiri, Senyum Lestari, Senyum Ramadhan, dan Super Qurban (https://www.rumahzakat.org).Dan juga LAZ Dompet Dhuafa memiliki Program Ekonomi, Program Pendidikan, Program Kesehatan dan Program Pengembangan Sosial (http://www.dompetdhuafa.org). Dan kesemuaan LAZ tentunya menawarkan kemudahan-kemudahan bagi Muzaki yang ingin menjadi donatur mereka, apakah itu jemput zakat, aplikasi hitung zakat dan lain sebagainya. Hal-hal tersebut tentunya akan memberikan daya tarik tersendiri bagi Muzaki maupun calon Muzaki dan akan menjadi bahan pertimbangan dimana harus memilih dan membayarkan ataupun menyalurkan zakatnya.

Persepsi apa yang mendasari muzaki lebih memilih LAZ yang satu ketimbang LAZ yang lainnya? Tentunya menjadi sangat menarik mengingat begitu banyak pilihan ketika muzaki menyalurkan zakatnya pada lembaga yang akan menerima amanah dari muzaki untuk mendistribusikannya. Pandangan maupun persepsi yang terbentuk dibenak muzaki tentunya berasal dari berbagai aspek dan banyak faktor. 
Sebagaimana persepsi adalah kemampuan otak dalam menerjemahkan stimulus atau proses untuk menerjemahkan stimulus yang masuk ke dalam alat indera manusia. Setiap individu mempunyai kecenderungan dalam melihat objek yang sama dengan cara yang berbeda-beda. Perbedaan tersebut dipengaruhi oleh banyak faktor, diantaranya adalah pengetahuan, pengalaman dan sudut pandang (Bachtir,2006:118) Hal ini lah yang kemudian memicu muzaki untuk memilih dan menetapkan pilihan pada LAZ mana yang akan dipilihnya.

Pilihan-pilihan terhadap sesuatu apapun itu, disebut dengan preferensi. Preferensi merupakan konsep abstrak yang menggambarkan peta peningkatan kepuasan yang diperoleh dari kombinasi barang dan jasa sebagai cerminan dari selera pribadi seseorang. Dengan kata lain preferensi konsumen merupakan gambaran tentang kombinasi barang dan jasa yang lebih disukai konsumen apabila ia memiliki kesempatan untuk memperolehnya (Simamora, 2003:87).

Persepsi dalam pandangan muzaki tentunya akan membentuk preferensi atau bisa dikatakan pilihan untuk menetapkan. Preferensi muzaki sendiri dalam memutuskan LAZ yang harus dipilih, menjadi tanda tanya bagi yang ingin mengetahuinya. Apakah pilihan-pilihan itu berasal dari indikator dalam diri yang berupa pengalaman selama ini ketika memutuskan selalu membayarkan zakatnya di salah satu LAZ atau adak indikator lain yang menjadi alasan dari muzaki tersebut.

Diakhir proses dari penalaran muzaki dalam memilih, yang tadinya diawali dari sebuah persepsi dari muzaki tentunya berujung pada menentukan atau pengambilan keputusan dimana dia akan membayarkan zakatnya. Muzaki yang telah memutuskan membayarkan zakatnya, biasanya terjadi 3 pilihan; tidak membayar lagi seterusnya dengan berbagai alasan, memilih LAZ lain dalam membayarkan zakatnya, atau seterusnya membayarkan zakatnya pada LAZ itu kembali.

Alasan-alasan yang terbentuk dari persepsi para muzaki yang kemudian menjadi preferensi selanjutnya memutuskan pilihan LAZ mana yang harus dipilih. Inilah yang ingin digali dan diteliti lebih dalam, sehingga diketahui bahwa persepsi apa yang mendasari muzaki dalam mengambil keputusan dalam memilih LAZ. Apapun alasan itu tentunya nanti harus menjadi konsen bagi LAZ untuk lebih mengkaji strategi apa yang harus dilakukan sehingga tercapailah tujuan untuk mencapai target zakat nasional.

Peneliti mencoba menfokuskan pada LAZ dan tidak mencoba membandingkan dengan unsur lainnya seperti pembayaran zakat melalui BAZ ataupun langsung kepada mustahiq. Hal ini dikarenakan terdapat kecenderungan bahwa muzaki lebih memilih membayarkan zakat pada LAZ sebagimana penelitian terdahulu oleh Yaumil Fauza 
(2013) dengan judul skripsi “Analisis Preferensi Masyarakat Dalam Memilih Institusi Pembayaran Zakat Di Kota Medan" bahwa sekitar 64,6\% Muzaki lebih memilih LAZ ketimbang BAZ, begitu juga penelitian Lisna Nety Herawati (2011) dengan judul skripsi "Preferensi dan Keputusan Masyarakat Kecamatan Karawaci Dalam Menyalurkan Zakat" yang hasil penelitiannya dimana responden lebih yakin akan membayarkan zakatnya melalui LAZ dibanding BAZ.

Masih sedikitnya penelitian dan artikel yang mengulas tentang perilaku konsumen khususnya membahas tentang preferensi muzaki dalam mengambil keputusan memilih Lembaga Amil Zakat membuat Peneliti tertarik untuk melakukan kajian secara mendalam. Penelitian ini secara mendalam tentunya akan menganalisis tentang kecenderuangan muzaki dalam memilih LAZ dalam menyalurkan zakatnya. Sebagai motivasi bagi Organisasi Pengelola Zakat dalam meningkatkan kualitas Lembaganya masing-masing.Maka untuk itu penelitian ini bertujuan untuk menganalisispengaruh persepsi terhadap preferensi Muzaki dalam keputusan memilih LAZ, kemudian untukmenganalisispengaruh Persepsi dan preferensi terhadap keputusan muzaki dalam memilih LAZ. Dan tentunya diharapkan menjadi rujukan ataupun dasar bagi Lembaga Amil Zakat dalam meningkatkan dan mengoptimalkan potensi zakat yang ada.

Untuk lebih memahami lebih, maka secara sitematika penulisan jurnal ini terdiri dari; Pendahuluan, Landasan Teori, Metode Penelitian, Hasil Pembahasan, Penutup (Kesimpulan dan Saran), dan Daftar Pustaka.

\section{LANDASAN TEORI}

Menurut Undang-Undang No. 38 Tahun 1999, Zakat adalah harta yang wajib di sisihkan oleh seorang muslim atau badan yang dimiliki oleh orang muslim sesuai dengan ketentuan agama untuk diberikan kepada yang berhak menerimanya. Sedangkan Muzaki adalah orang atau badan yang dimiliki oleh orang Muslim yang bekewajiban menunaikan zakat( UU No.38 Tahun 1999), Jadi hubungan keduanya bahwa zakat merupakan sesuatu kewajiban yang harus dilaksanakan dan muzaki adalah nama bagi orang yang melakukan kewajiban zakat tersebut.

Persepsi menurut Webster sebagaimana dikutip oleh Sutisna yang menyatakan persepsi adalah proses bagaimana stimulus-stimulus (yang mempengaruhi tanggapan-tanggapan itu diseleksi dan diinterpretasikan, persepsi setiap orang terhadap suatu objek itu berbeda-beda oleh karena itu persepsi mempunyai sifat subyektif. Stimulus adalah setiap bentuk fisik atau komunikasi verbal yang dapat mempengaruhi tanggapan individu. Salah satu stimulus yang penting yang dapat mempengaruhi perilaku konsumen adalah lingkungan (sosial dan budaya) karena persepsi setiap orang 
terhadap suatu objek akan berbeda-bada oleh karena itu persepsi mempunyai sifat subjektif. Persepsi seorang konsumen akan berbagai stimulus yang diterimanya di pengaruhi oleh karakteristik yang dimilikinya

Pelayanan adalah setiap tindakan atau kegiatan yang dapat ditawarkan oleh suatu pihak kepada pihak lain, yang pada dasarnya tidak berwujud dan tidak mengakibatkan kepemilikan apapun. Produksinya dapat dikaitkan atau tidak dikaitkan pada satu produk fisik. Pelayanan merupakan perilaku produsen dalam rangka memenuhi kebutuhan dan keinginan konsumen demi tercapainya kepuasan pada konsumen itu sendiri (Sutisna, 2001: 63).

Kotler juga mengatakan bahwa perilaku pelayanan dapat terjadi pada saat, sebelum dan sesudah terjadinya transaksi. Pada umumnya pelayanan yang bertaraf tinggi akan menghasilkan kepuasan yang tinggi serta pembelian ulang yang lebih sering. Kata kualitas mengandung banyak definisi dan makna, orang yang berbeda akan mengartikannya secara berlainan tetapi dari beberapa definisi yang dapat kita jumpai memiliki beberapa kesamaan walaupun hanya cara penyampaiannya saja biasanya terdapat pada elemen yaitu, Kualitas meliputi usaha memenuhi atau melebihkan harapan pelanggan, Kualitas mencakup produk, jasa, manusia, proses dan lingkungan, Kualitas merupakan kondisi yang selalu berubah (Kotler dan Armstrong, 2008:83).

Indikator dalam ukuran penilaian persepsi pelayanan adalah sebagai berikut:Tangibles (Fasilitas Fisik);Credibility (Kredibilitas); Competence (Kompeten); Acces (akses);Reliability (Reliabilitas);Responsiveness (Responsif); Courtesy (Kesopanan); Communication (Komunikasi); Understanding The Customer(Memahami Pelanggan);Security (Keamanan)( Laksana, 2008:90).

Promosi adalah suatu komunikasi informasi penjual dan pembeli yang bertujuan untuk merubah sikap dan tingkah laku pembeli, yang sebelumnya tidak mengenal menjadi mengenal sehingga menjadi pembeli dan mengingat produk tersebut ( Saladin dan Oesman, 2002:123).

Indikator yang mencirikan promosi yang digunakan dalam penelitian ini, yaitu: (Saladin, 2004:172) Periklanan (Advertising), Promosi Penjualan (Sales Promotion), Hubungan masyarakat dan Publisitas (Public Relation and Publicity), Penjualan Persoanal (Personal Selling), dan Pemasaran Langsung (Direct Marketing.)

Lokasi merupakan letak atau toko pengecer pada daerah yang strategis sehingga dapat memaksimumkan laba (Swashta dan Sukotjo, 2010: 339).Alasan bagi keputusan pemilihan lokasi menjadi lebih penting untuk di pertimbangkan. Mengingat, se- 
makin banyak ritel membuka lokasi baru sedangkan lokasi yang paling baik, sangatlah sulit untuk didapatkan. Lokasi merupakan tempat dimana perusahaan harus bermarkas melakukan operasi (Lupiyoadi, : 2008: 61).

Preferensi konsumen merupakan gambaran tentang kombinasi barang dan jasa yang lebih disukai konsumen apabila ia memiliki kesempatan untuk memperolehnya. Preferensi juga diartikan sebagai derajat kesukaan seseorang terhadap suatu jenis produk. Preferensi dapat terbentuk melalui pola pikir konsumen yang didasari oleh beberapa alasan, antara lainPengalaman, Kepercayaan, Atribut, Kepentingan, Kepuasan(Simamora,2003:87).

Pengertian keputusan pembelian adalah tahap dalam proses pengambilan keputusan pembeli di mana konsumen benar-benar membeli. Pengambilan keputusan merupakan suatu kegiatan individu yang secara langsung terlibat dalam mendapatkan dan mempergunakan barang yang ditawarkan (Bilondatu, 2013:711).

\section{Kerangka Teori}

Model konseptual yang didasarkan pada uraian sebelumnya, kerangka pemikiran teoritis penelitian dijelaskan pada gambar sebagai berikut:

Gambar 1

Kerangka Teori

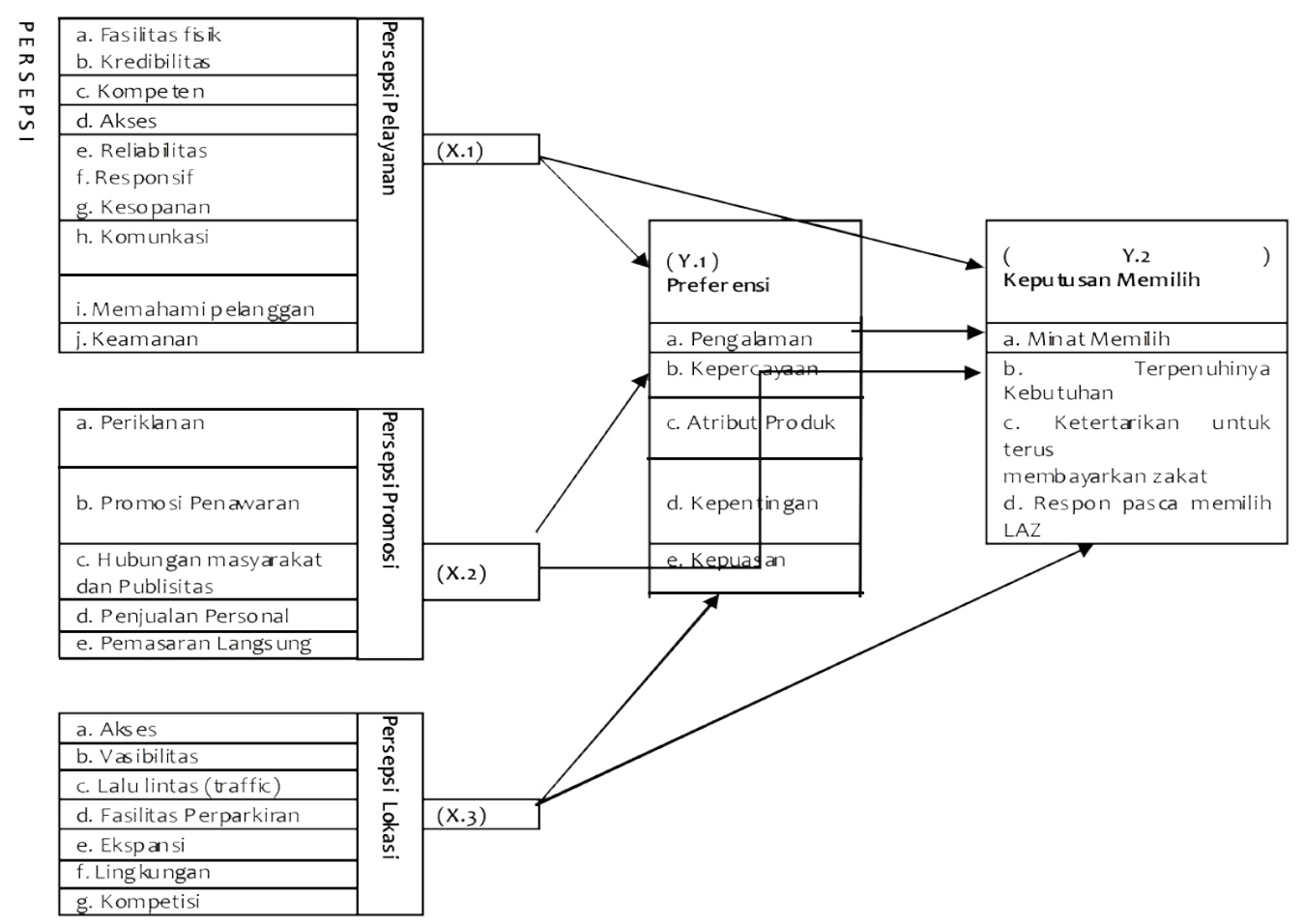




\section{METODE PENELITIAN}

Populasi pada penelitian ini adalah muzaki yang membayarkan zakatnya pada Lembaga Amil Zakat; Rumah Zakat, Dompet Dhuafa, dan Inisiatif Zakat Indonesia yang merupakan Lembaga Amil Zakat Nasional dengan kantor perwakilan di Sumatera Utara. Ketiga Lembaga Amil Zakat tersebut memiliki kantor perwakilan yang berdomisili di Kota Medan sehingga mayoritas muzakinya adalah masyarakat muslim yang berdomisi di Kota Medan dan sekitarnya seperti di Kota Binjai dan Kabupaten Deli Serdang. Pada penelitian ini dilakukan penyebaran kuesioner pada 100 responden yang menjadi sampel (Roscoe, 1975: 64).

Jenis penelitian ini adalah penelitian kuantitatif menggunakan metode analisis jalur (path analisis) dengan tools aplikasi LISREL 8.80 yang dibantu dengan MSI (Method of Succesive Interval)dan SPSS 16.0 untuk Uji kelayakan datanya. Diagram dan hipotesa yang dibangun sebagai berikut:

\section{Gambar 2}

\section{Diagram Analisis Jalur}

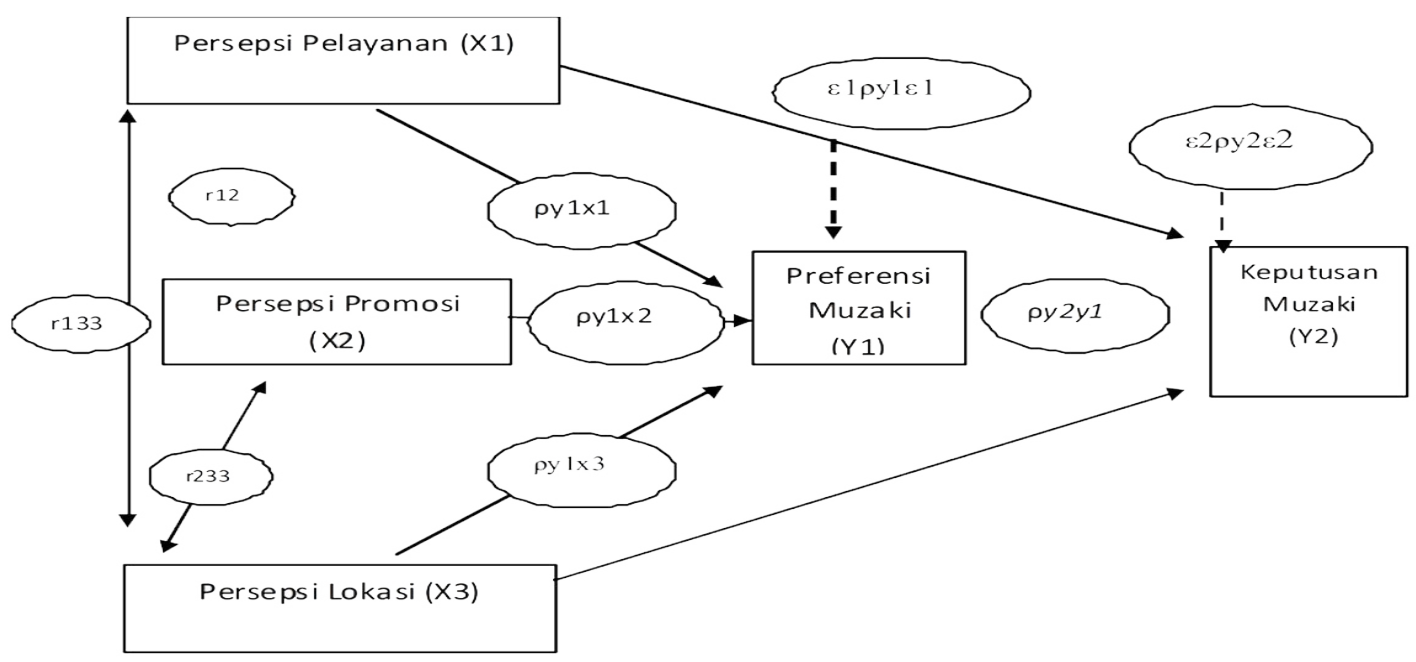

$\begin{array}{lll}\text { Struktur I } & \rightarrow & Y 1=\rho y 1 \times 1+\rho y 1 \times 2+\rho y 1 \times 3+\rho y 1 \varepsilon 1 \\ \text { Struktur II } & \rightarrow & Y 2=\rho y 2 \times 1+\rho y 2 \times 2+\rho y 2 \times 3+\rho y 2 y 1+\rho y 2 \varepsilon 2\end{array}$

Hipotesis:

Struktur I Y1 = $\rho y 1 \times 1+\rho y 1 \times 2+\rho y 1 \times 3+\rho y 1 \varepsilon 1$

Ha1 : Persepsi pelayanan, promosi dan lokasi berkontribusi secara simultan terhadap preferensi muzaki

Ha2 : Persepsi pelayanan berkontribusi secara parsial terhadap preferensi muzaki. 
Ha3 : Persepsi promosi berkontribusi secara parsial terhadap preferensi muzaki.

Ha4 : Persepsi lokasi berkontribusi secara parsial terhadap preferensi muzaki.

Struktural Y2 $=\rho y 2 \times 1+\rho y 2 \times 2+\rho y 2 \times 3+\rho y 2 y 1+\rho y 2 \varepsilon 2$

Ha5 : Persepsi pelayanan, promosi, lokasi dan preferensi muzaki berkontribusi secara simultan terhadap keputusan muzaki.

Ha6 : Persepsi pelayanan berkontribusi secara parsial terhadap keputusan muzaki, (Pengaruh Langsung dan Pengaruh Tidak Langsung Persepsi pelayanan terhadap keputusan muzaki memilih LAZ).

Ha7 : Persepsi promosi berkontribusi secara parsial terhadap keputusan muzaki, (Pengaruh Langsung dan Pengaruh Tidak Langsung Persepsi promosi terhadap keputusan muzaki memilih LAZ)

Ha8: Persepsi lokasi berkontribusi secara parsial terhadap keputusan muzaki, (Pengaruh Langsung dan Pengaruh Tidak Langsung lokasi terhadap keputusan muzaki memilih LAZ).

Ha9: Preferensi berkontribusi secara parsial terhadap keputusan muzaki.

\section{HASIL DAN PEMBAHASAN}

Penelitian ini berlokasi di Kota Medan dan sekitarnya. Dipilihnya Kota Medan dengan alasan bahwa Organisasi Pengelolah Zakat Tingkat Provinsi berdomisili di Kota Medan karena merupakan Ibu Kota Provinsi, sehingga Muzaki yang membayar zakat pada OPZ tersebut banyak didominasi oleh Muzaki yang tinggal di daerah tersebut maupun disekitarnya seperti daerah Kabupaten Deli Serdang mapun Kota Binjai yang secara wilayah bertetangga dengan Kota Medan. Penelitian ini dilakukan pada Desemeber 2016 sampai dengan Januari 2017. Adapun Lembaga Amil Zakat yang muzakkinya dipilih sebagai responden adalah 3 (Tiga) Lembaga Amil Zakat, yaitu: LAZ Dompet Dhuafa, LAZ Rumah Zakat, dan LAZ Inisiatif Zakat Indonesia.

Tabel 1

Uji Validitas

\begin{tabular}{|l|l|l|l|l|}
\hline No & Pernyataan/Pertanyaan Persepsi Pelayanan & r-Hitung & r-Tabel & Hasil \\
\hline 1 & Fasilitas Gedung LAZ baik & 0,3795 & 0,195 & Valid \\
\hline 2 & $\begin{array}{l}\text { Tata letak tampilan barang terlihat baik dan } \\
\text { rapi }\end{array}$ & 0,4963 & 0,195 & Valid \\
\hline 3 & Saya merasa nyaman berada di kantor LAZ & 0,3614 & 0,195 & Valid \\
\hline 4 & $\begin{array}{l}\text { Peralatan dan perlengkapan LAZ termasuk } \\
\text { modern }\end{array}$ & 0,3841 & 0,195 & Valid \\
\hline 5 & LAZ termasuk tepercayaan & 0,4778 & 0,195 & Valid \\
\hline
\end{tabular}




\begin{tabular}{|c|c|c|c|c|}
\hline 6 & LAZ mampu meyakinkan & 0,5963 & 0,195 & Valid \\
\hline 7 & $\begin{array}{l}\text { LAZ termasuk menjunjung kejujuran dalam } \\
\text { pelayanan }\end{array}$ & 0,5870 & 0,195 & Valid \\
\hline 8 & $\begin{array}{l}\text { Petugas LAZ terampil dan memiliki pengeta- } \\
\text { huan yang baik }\end{array}$ & 0,6058 & 0,195 & Valid \\
\hline 9 & LAZ Memberikan/menyediakan keinginan saya & 0,3198 & 0,195 & Valid \\
\hline 10 & $\begin{array}{l}\text { LAZ selalu Efektif dalam memberi Informasi } \\
\text { Jasa }\end{array}$ & 0,5161 & 0,195 & Valid \\
\hline 11 & LAZ memberi bukti penyaluran & 0,4678 & 0,195 & Valid \\
\hline 12 & LAZ selalu mencatat Nota/Kwitansi/Bukti & 0,5405 & 0,195 & Valid \\
\hline 13 & $\begin{array}{l}\text { LAZ selalu Membantu dengan segera me- } \\
\text { mecahkan masalah }\end{array}$ & 0,4802 & 0,195 & Valid \\
\hline 14 & Petugas LAZ sopan dan ramah & 0,5604 & 0,195 & Valid \\
\hline 15 & Petugas LAZ berkomunikasi yang baik & 0,6110 & 0,195 & Valid \\
\hline 16 & $\begin{array}{l}\text { LAZ Mengerti dan memahami kebutuhan mu- } \\
\text { zaki }\end{array}$ & 0,5736 & 0,195 & Valid \\
\hline 17 & LAZ Memberikan rasa nyaman & 0,7012 & 0,195 & Valid \\
\hline No & Pernyataan/Pertanyaan Persepsi Promosi & r-Hitung & r-Tabel & Hasil \\
\hline 1 & LAZ menyajian iklan yang baik & 0,4022 & 0,195 & Valid \\
\hline 2 & $\begin{array}{l}\text { LAZ mempromosikan penawaran yang mempu- } \\
\text { nyai daya tarik }\end{array}$ & 0,2603 & 0,195 & Valid \\
\hline 3 & $\begin{array}{l}\text { LAZ selalu menjalin hubungan terhadap mas- } \\
\text { yarakat tetap terjaga. }\end{array}$ & 0,3487 & 0,195 & Valid \\
\hline 4 & $\begin{array}{l}\text { Petugas menawarkan secara pribadi membuat } \\
\text { saya tertarik. }\end{array}$ & 0,3443 & 0,195 & Valid \\
\hline 5 & $\begin{array}{l}\text { Penawaran secara langsung melalui berbagai } \\
\text { media }\end{array}$ & 0,2519 & 0,195 & Valid \\
\hline No & Pernyataan/Pertanyaan Persepsi Lokasi & r-Hitung & r-Tabel & Hasil \\
\hline 1 & $\begin{array}{l}\text { Kantor LAZ memiliki Lokasi yang dilalui atau } \\
\text { mudah dijangkau sarana transportasi umum }\end{array}$ & 0,2065 & 0,195 & Valid \\
\hline 2 & $\begin{array}{l}\text { Kantor LAZ Lokasinya dapat dilihat dengan } \\
\text { jelas dari jarak pandang normal }\end{array}$ & 0,2137 & 0,195 & Valid \\
\hline 3 & $\begin{array}{l}\text { Didepan kantor LAZ Banyak orang yang la- } \\
\text { lu-lalang }\end{array}$ & 0,2223 & 0,195 & Valid \\
\hline 4 & Tempat parkir yang nyaman & 0,3201 & 0,195 & Valid \\
\hline 5 & Tempat parkir yang aman & 0,3154 & 0,195 & Valid \\
\hline 6 & Tempat yang cukup luas & 0,3125 & 0,195 & Valid \\
\hline 7 & $\begin{array}{l}\text { Daerah sekitar yang mendukung jasa yang } \\
\text { ditawarkan }\end{array}$ & 0,4466 & 0,195 & Valid \\
\hline 8 & Lokasi kantor LAZ lain dekat & 0,3516 & 0,195 & Valid \\
\hline
\end{tabular}


Satria, Saparuddin, Mustafa: Lembaga Amil Zakat

\begin{tabular}{|l|l|l|l|l|}
\hline No & Pernyataan/Pertanyaan Preferensi & r-Hitung & r-Tabel & Hasil \\
\hline 1 & Saya sudah merasa cocok dengan LAZ & 0,3048 & 0,195 & Valid \\
\hline 2 & Saya yakin dan percaya LAZ sesuai amanah & 0,3187 & 0,195 & Valid \\
\hline 3 & LAZ selama ini mudah terjangkau & 0,3517 & 0,195 & Valid \\
\hline 4 & $\begin{array}{l}\text { LAZ selama ini sangat membantu menyalurkan } \\
\text { zakat }\end{array}$ & 0,2643 & 0,195 & Valid \\
\hline 5 & $\begin{array}{l}\text { Saya merasa puas ketika menunaikan memba- } \\
\text { yar zakat pada LAZ }\end{array}$ & 0,5189 & 0,195 & Valid \\
\hline No & Pernyataan/Pertanyaan Keputusan & r-Hitung & r-Tabel & Hasil \\
\hline 1 & $\begin{array}{l}\text { Keputusan memilih LAZ karena adanya minat } \\
\text { memilih yang muncul dari diri sendiri }\end{array}$ & 0,4723 & 0,195 & Valid \\
\hline 2 & $\begin{array}{l}\text { Keputusan memilih LAZ karena ingin ter- } \\
\text { penuhinya kebutuhan akan membayarkan } \\
\text { zakat }\end{array}$ & 0,2230 & 0,195 & Valid \\
\hline 3 & Saya akan trrus membayar zakat melalui LAZ & 0,3452 & 0,195 & Valid \\
\hline 4 & $\begin{array}{l}\text { Merekomendasikan pihak lain untuk memilih } \\
\text { LAZ yang sama }\end{array}$ & 0,2235 & 0,195 & Valid \\
\hline
\end{tabular}

Dapat dilihat pada tabel tersebut di atas terlihat bahwa keempat instrumen data dikategorikan valid karena r-hitung lebih besar dari r-tabel = 0,195 (semua nilai r-hitung > dari r-tabel).

Untuk uji realibilitas pada penelitian ini menggunakan program MSI (Method of Succesive Interval), berikut hasil uji reliabilitas dimaksud:

Tabel 2

Uji Reliabilitas

\begin{tabular}{|l|l|}
\hline & \multicolumn{2}{|l|}{$\begin{array}{l}\text { Reliability \& item anal- } \\
\text { ysis }\end{array}$} \\
\hline & Scale Mean $: 134.2433$ \\
\hline & Variance : 192.1801 \\
\hline & Scale Std :13.8629 \\
\hline & Alpha : :8635 \\
\hline & Max : 165.3695 \\
\hline & Min : 102.3941 \\
\hline (Hair, > 0,70) & Cron. Alpha $: .8634$ \\
\hline
\end{tabular}

Tabel tersebut di atas menunjukkn hasil bahwa nilai Cronbach's Alpha yang dihasilkan oleh output MSI adalah sebesar 0,8634 artinya semua item pernyataan ataupun per- 
tanyaan instrumen yang dibuat adalah Reliabel karena nilai Cronbach's Alpha yang dihasilkan lebih besar dari 0,7 (0,8634>0,7).

Tabel 3

Hasil Uji Normalitas Lisrel

Test of Univariate Normality for Continuous Variables

\begin{tabular}{|c|c|c|c|c|c|c|}
\hline \multirow[b]{2}{*}{ Variable } & \multirow{2}{*}{$\begin{array}{l}\text { Skew- } \\
\text { ness } \\
\text { Z-Score }\end{array}$} & \multirow[b]{2}{*}{ P-Value } & \multicolumn{2}{|l|}{ Kurtosis } & \multicolumn{2}{|c|}{ Skewness and Kurtosis } \\
\hline & & & Z-Score & P-Value & Chi-Square & P-Value \\
\hline $\begin{array}{l}\text { X1_PE- } \\
\text { LAY }\end{array}$ & -0.321 & 0.748 & -1.896 & 0.058 & 3.696 & 0.158 \\
\hline $\begin{array}{l}\mathrm{X} 2 \text { _PRO- } \\
\mathrm{MO}\end{array}$ & -1.424 & 0.155 & -0.747 & 0.455 & 2.584 & 0.275 \\
\hline $\begin{array}{l}\mathrm{X}_{3} \mathrm{LO}- \\
\mathrm{KAS}\end{array}$ & 0.114 & 0.909 & -2.140 & 0.032 & 4.591 & 0.101 \\
\hline $\begin{array}{l}\text { Y1 } \\
\text { PREFE }\end{array}$ & -1.200 & 0.230 & -0.993 & 0.321 & 2.427 & 0.297 \\
\hline $\begin{array}{l}\mathrm{Y}_{2} \\
\mathrm{KEPUT}\end{array}$ & -1.854 & 0.064 & -0.797 & 0.425 & 4.071 & 0.131 \\
\hline
\end{tabular}

Dari hasil output normalitas data tersebut diatas dapat dijelaskan bahwa seluruh data berdistribusi secara normal. Untuk melihat data yang dikatakan berdistribusi normal jika nilai $P$-Value pada Skewness dan Kurtosis lebih besar dari 0,05. Pada variabel pelayanan nilai $P$-Valuenya adalah 0,158 lebih besar dari 0,05 maka dapat dikatakan normal. Begitu juga variabel promosi 0,275, variabel lokasi 0,101, variabel preferensi 0,297, dan variabel keputusan 0,131. Kesemua nilai $P$-Value variabel tersebut lebih besar dari 0,05. Maka dapat disimpulkan bahwa data dalam penelitian ini berdistribusi normal keseluruhannya.

Dari hasil uji multikoleritas bahwa nilai VIF (variance-inflating factor) untuk semua variabel independen lebih kecil dari 10, yaitu variabel pelayanan 1,181, variabel promosi 1,440 dan variabel lokasi 1,313 artinya data tersebut terbebas dari multikolonieritas. Selanjutnya ditambah dengan preferensi keseluruhan variabel bahwa nilai VIF (variance-inflating factor) untuk semua variabel independen lebih kecil dari 10, yaitu variabel pelayanan 1,391, variabel promosi 1,471, variabel lokasi 1,313 dan variabel preferensi 1,528 artinya data tersebut terbebas dari multikolonieritas.

Untuk hasil output SPSS pada uji linieritas maka disimpulkan bahwa nilai Sig. pada Deviation from Linierity yakni Y1_Preferensi*X1_Pelayanan adalah 0,210 lebih besar 
dari 0,05, Y2_Keputusan*X1_Pelayanan adalah 0,323 lebih besar dari 0,05. Kemudian nilai Sig. pada Deviation from Linierity yakni Y1_Preferensi*X2_Promosi adalah 0,546 lebih besar dari 0,05, Y2_Keputusan*X2_Promosi adalah 0,217 lebih besar dari 0,05. Selanjutnya nilai Sig. pada Deviation from Linierity yakni $Y_{1}$ Preferensi* $X_{3}$ Lokasi adalah 0,127 lebih besar dari 0,05, Y2_Keputusan*X3_Lokasi adalah 0,251 lebih besar dari 0,05 . Maka semua data tersebut dapat dikatakan bersifat linier. Yang terakhir nilai Sig. pada Deviation from Linierity yakni Y2_Keputusan*Y1_Preferensi adalah 0,051 lebih besar dari 0,05. Dan keseluruhan data tersebut tersebut dapat dikatakan bersifat linier.

\section{Analisis Jalur (Path Analisis)}

Pada path diagram yang menggambarkan koefisien jalur untuk masing masing jalur. Koefisien tersebut sama dengan hasil pada persamaan structural. Berikut hasil Output Structural Equation Model Path Analisis Diagram:

\section{Gambar3}

\section{Hasil Estimasi Analisis Jalur}
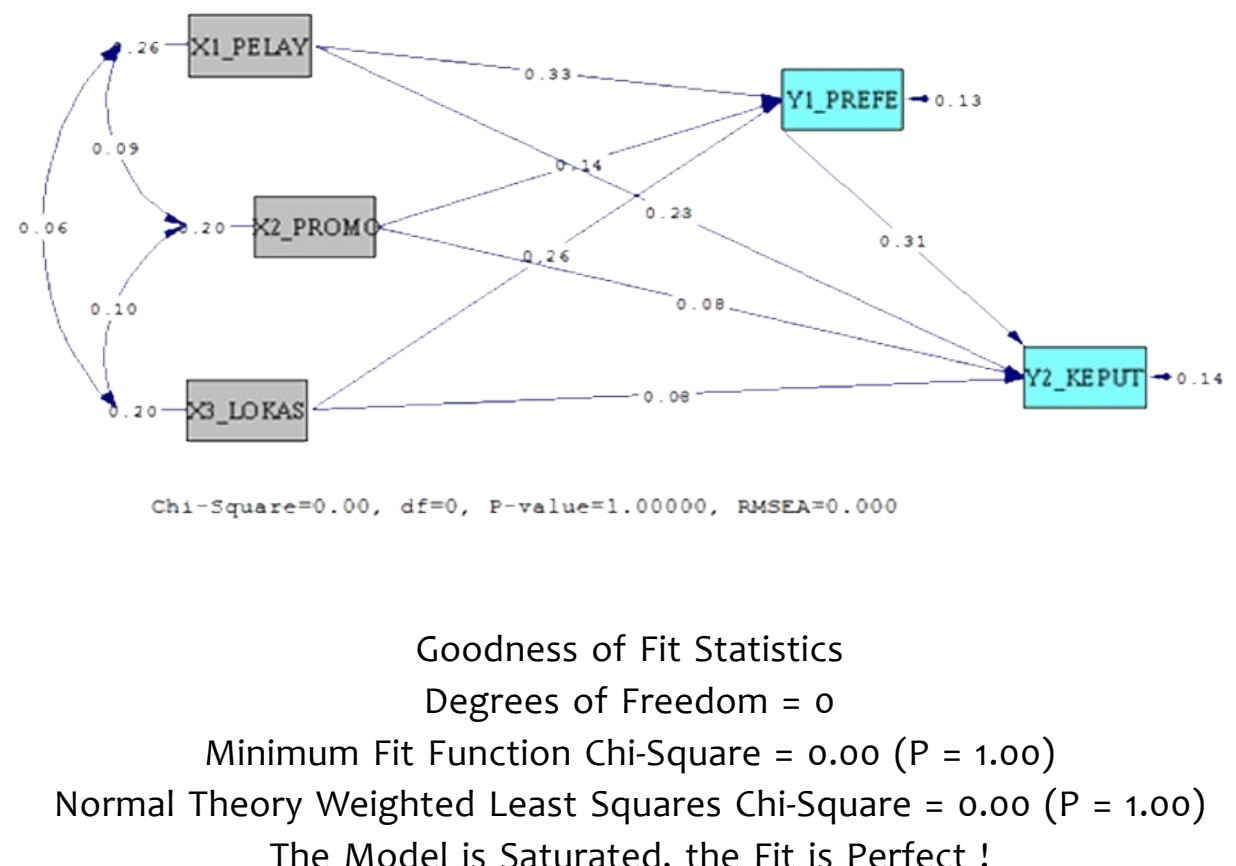

Diagram tersebut dan output yang dihasilkan memberikan arti bahwa model memiliki fit yang sangat baik. Hasil yang baik ditunjukkan apabila memiliki nilai chi-square $=0,00$ dan Padalah 1 ( $>$ > 0,05). Menurut Ghazali dan Fuad (Ghazali dan Fuad, 2005: 29) bahwa nilai chi-square merupakan ukuran mengenai baik buruknya fit suatu model dan nilai chi-square sebesar o menunjukkan model memiliki fit yang sempurna (fit is perfect). 
Hasil output lisrel mengenai kovarian matriks dapat dilihat pada hasil output di bawah ini:

Tabel 4

Hasil Output LisrelCovariance Matrix

\begin{tabular}{|l|c|c|c|c|c|}
\hline & Y1_PREFE & Y2_KEPUT & X1_PELAY & X2_PROMO & X3_LOKAS \\
\hline Y1_PREFE & 0.20 & & & & \\
\hline $\begin{array}{l}\text { Y2_ } \\
\text { KEPUT }\end{array}$ & 0.10 & 0.21 & & & \\
\hline $\begin{array}{l}\text { X1_PE- } \\
\text { LAY }\end{array}$ & 0.11 & 0.11 & 0.26 & & \\
\hline $\begin{array}{l}\text { X2_PRO- } \\
\text { MO }\end{array}$ & 0.08 & 0.07 & 0.09 & 0.20 & \\
\hline $\begin{array}{l}\text { X3_LO- } \\
\text { KAS }\end{array}$ & 0.08 & 0.06 & 0.06 & 0.10 & 0.20 \\
\hline
\end{tabular}

Matriks tersebut diatas menunjukkan hubungan linier yang terjadi diantara dua variabel. Jika suatu variabel memiliki hubungan linier yang positif, maka nilai kovariansnya adalah positif (vice versa). Jika tidak terdapat hubungan diantara dua variabel, nilai kovariansnya adalah Nol. Nilai kovarians tidak terbatas, bisa positif dan bisa negative.

Dari matriks tersebut, dapat diketahui bahwa kovarians matriks antar variabel dimana kovarians variabel preferensi terhadap preferensi sendiri adalah 0,20. Preferensi dan keputusan adalah 0,10. Variabel preferensi dengan pelayanan adalah 0,11. Kovarians preferensi dan promosi adalah 0,08. Kovarians preferensi dengan lokasi adalah 0,08. Kovarians keputusan dan preferensi adalah o. Kovarians keputusan terhadap keputusan itu sendiri adalah 0,21. Kovarians keputusan dengan pelayanan 0,11. Kovarians keputusan dan promosi 0,07. Kovarians keputusan dan lokasi adalah 0,06.

Untuk Structural Equation menunjukkan bahwa ini merupakan persamaan structural yang dihasilkan oleh output LISREL. Ada dua persamaan structural structural yang dihasilkan yaitu yang pertama:

\section{Gambar 4}

Hasil Output LisrelStructural Equations

$\mathrm{Y} 1 \_\mathrm{PREFE}=0.33 * \mathrm{X} 1 \_\mathrm{PELAY}+0.14 * \mathrm{X} 2 \_\mathrm{PROMO}+0.26 * \mathrm{X} 3 \_$LOKAS, Errorvar. $=0.13, \mathrm{R}^{2}$ $=0.35$
$(0.080)$
$(0.099)$
(0.096)
(0.019)
4.13
1.44
2.68
6.93 
Persamaan struktural tersebut menunjukkan bahwa variabel pelayanan berpengaruh terhadap variable preferensi dengan besarnya pengaruh sebesar 0,33 dan standar error sebesar 0,08. Pengaruh tersebut signifikan, hal ini bias dilihat dari nilai t-hitung sebesar 4,13, nilai ini lebih besar dari nilai t-tabel yakni1,95 (t-hitung > t-tabel yaitu $4,13>1,95)$. Sedangkan variable promosi secara parsial mempengaruhi variable preferensi sebesar 0,14 dengan standar error 0,09, akan tetapi pengaruh tersebut tidak signifikan karena t-hitung lebih kecil dari t-tabel yaitu 1,44<1,95. Sementara hal yang sama dengan variable pelayanan, variabel lokasi juga berpengaruh signifikan terhadap variable preferensi dengan besarnya pengaruh sebesar 0,26 dan standar error sebesar 0,096. Pengaruh variable lokasi tersebut signifikan, hal ini bisa dilihat dari nilai t-hitung sebesar 2,68, nilai ini lebih besar dari nilai t-tabel yakni1,95 (t-hitung > t-tabel yaitu 2,68 >1,95)

Berarti secara simultan tidak semuanya berpengaruh signifikan terhadap variabel endogen (variabel preferensi).Dari 3 (tiga) Variabel tersebut yaitu variabel pelayanan, promosi dan lokasi terdapat 2 (dua) variabel; variabel pelayanan dan variabel lokasi yang berpengaruh signifikan dan yang 1 (satu) variabel; variabel promosi hanya berpengaruh secara parsial terhadap variabel preferensi. Dari sini dapat diketahui nilai koefisien determinan (R2) sebesar 0,35 atau 35\%, artinya variable pelayanan, promosi dan lokasi mempengaruhi variabel preferensi sebesar 35\%, sedangkan sisanya sebesar $65 \%$ dipengaruhi oleh variabel lain yang tidak dilibatkan dalam penelitian ini.

Persamaan structural yang kedua yang dihasilkan adalah sebagai berikut:

Gambar 5

Hasil Output Lisrel

Y2_KEPUT $=0.31 * Y_{1}$ PREFE $+0.23 * X_{1}$ PELAY $+0.080 * X_{2}$ PROMO $+0.075 * X_{3}$ LO $\mathrm{KAS}$, Errorvar. $=0.14, \mathrm{R}^{2}=0.32$
$(0.11)$
(0.089)
$(0.10)$
$(0.10)$
$(0.020)$
2.97
2.59
0.77
0.73
6.93

Persamaan struktural kedua ini menunjukkan bahwa variabel preferensi berpengaruh terhadap variabel keputusan dengan besarnya pengaruh sebesar 0,31 dan standar error sebesar 0,11. Pengaruh tersebut signifikan, hal ini bias dilihat dari nilai t-hitung sebesar 2,97, nilai ini lebih besar dari nilai t-tabel yakni1,95 (t-hitung > t-tabel yaitu 2,97 > 1,95). Variabel Pelayanan juga berpengaruh secara signifikan terhadap variable keputusan dengan besarnya pengaruh sebesar 0,23 dan standar error sebesar 0,089. Signifikan pengaruh variabel pelayanan terhadap variabel keputusan bisa dilihat dari nilai t-hitung sebesar 2,95, nilai ini lebih besar dari nilai t-tabel yakni1,95 
(t-hitung > t-tabel yaitu 2,95 >1,95). Sedangkan variable promosi secara parsial mempengaruhi variable preferensi sebesar 0,08 dengan standar error 0,10, akan tetapi pengaruh tersebut tidak signifikan karena t-hitung lebih kecil dari t-tabel yaitu $0,77<$ 1,95. Sementara hal yang sama dengan variabel promosi, variabel lokasi berpengaruh terhadap variabel keputusan dengan besarnya pengaruh hanya sebesar 0,075 dan standar error sebesar 0,10. Pengaruh variable lokasi tersebut tidak signifikan, hal ini bisa dilihat dari nilai t-hitung sebesar 0,73, nilai ini lebih kecil dari nilai t-tabel yakni1,95 (t-hitung < t-tabel yaitu $0,73<1,95$ ).

Secara simultan keempat variabel tersebut di atas tidak semuanya berpengaruh signifikan terhadap variabel endogen (variabel keputusan). Dari 4 (empat) Variabel tersebut yaitu variabel preferensi, pelayanan, promosi dan lokasi terdapat 2 (dua) variabel; variabel preferensi dan variabel pelayanan yang berpengaruh signifikan dan yang 2 (dua) variabel lagi; variabel promosi dan lokasi hanya berpengaruh secara parsial terhadap variabel keputusan. Dan dapat diketahui nilai koefisien determinan (R2) sebesar 0,32 atau 32\%, artinya dalam penelitian ini variabel preferensi, pelayanan, promosi dan lokasi mempengaruhi variabel keputusan sebesar $32 \%$, sedangkan sisanya sebesar $68 \%$ dipengaruhi oleh variabel lain yang tidak dilibatkan.

Untuk path diagram yang menunjukkan tingkat signifikansi masing-masing variabel eksogen terhadap variabel endogen bisa dlihat pada gambar berikut :

Gambar 6

Path Diagram t-Value Output Lisrel

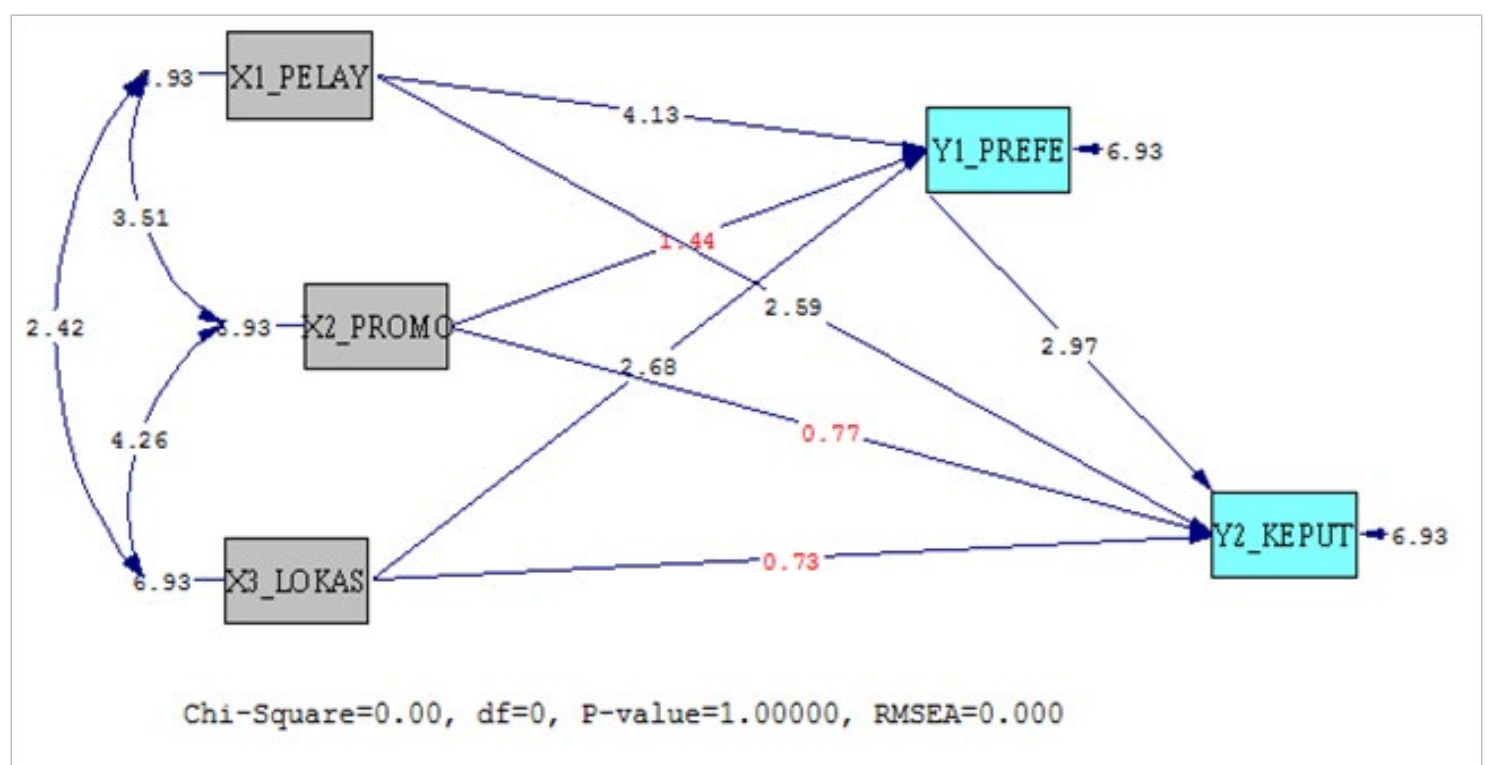


Dapat dengan mudah diketahui apakah variabel eksogen mempunyai pengaruh signifikan terhadap variabel endogen yaitu; dengan melihat angka, apakah angka tersebut berwarna merah atau berwarna hitam.Jika angka tersebut berwarna merah maka variabel eksogen tidak mempunyai pengaruh yang signifikan terhadap variabel endogen. Dalam diagram tersebut dapat dilihat bahwa variabel promosi tidak mempunyai pengaruh signifikan terhadap variabel preferensi (1,44 "angka merah) dan terhadap variabel keputusan (0,77 "angka merah). Begitu juga variabel lokasi yang tidak berpengaruh signifikan terhadap variabel keputusan (0,73 "angak merah). Angka berwarna merah tersebut merupakan t-hitung yang dihasilkan oleh LISREL, yang dengan diagram tersebut dapat mempermudah menjelaskan hasil output path analisis.

Tabel 5

Hasil Output Total and Indirect Effects

\begin{tabular}{|c|c|c|c|}
\hline \multicolumn{4}{|c|}{ Total Effects of $X$ on $Y$} \\
\hline & X1_PELAY & X2_PROMO & $X_{3}$ LOKAS \\
\hline \multirow[t]{3}{*}{ Y1_PREFE } & 0.33 & 0.14 & 0.26 \\
\hline & $(0.08)$ & $(0.10)$ & $(0.10)$ \\
\hline & 4.13 & 1.44 & 2.68 \\
\hline \multirow[t]{3}{*}{$\mathrm{Y}_{2}$ KEPUT } & 0.33 & 0.12 & 0.16 \\
\hline & $(0.09)$ & $(0.11)$ & $(0.10)$ \\
\hline & 3.89 & 1.16 & 1.51 \\
\hline \multicolumn{4}{|c|}{ Indirect Effects of $X$ on $Y$} \\
\hline & X1_PELAY & $\mathrm{X} 2$ PROMO & $X_{3}$ LOKAS \\
\hline Y1_PREFE & -- & -- & - \\
\hline \multirow[t]{3}{*}{ Y2_KEPUT } & 0.10 & 0.04 & 0.08 \\
\hline & $(0.04)$ & $(0.03)$ & $(0.04)$ \\
\hline & 2.41 & 1.30 & 1.99 \\
\hline \multicolumn{4}{|c|}{ Total Effects of $Y$ on $Y$} \\
\hline & Y1_PREFE & $\mathrm{Y}_{2}$ KEEPUT & \\
\hline \multicolumn{4}{|l|}{ Y1_PREFE } \\
\hline \multirow[t]{3}{*}{ Y2_KEPUT } & 0.31 & - & \\
\hline & $(0.11)$ & & \\
\hline & 2.97 & & \\
\hline \multicolumn{4}{|c|}{ Largest Eigenvalue of $B^{*} B^{\prime}$ (Stability Index) is 0.098} \\
\hline
\end{tabular}


Matriks Total Effectsof $\mathrm{X}$ on $\mathrm{Y}$ menjelaskan mengenai total pengaruh variabel eksogen terhadap variabel endogen. Sedangkan Matriks Indirect Effect menjelaskan pengaruh tidak langsung. Dan Matriks Total Effect of $\mathrm{Y}$ on $\mathrm{Y}$ menjelaskan mengenai pengaruh total variabel endogen terhadap variabel endogen lainnya. Hasil tersebut bisa kita rekap sebagai berikut :

Tabel 6

Pengaruh Langsung, Tidak Langsung dan Pengaruh Total

\begin{tabular}{|l|l|l|l|}
\hline $\begin{array}{l}\text { Hubungan Struk- } \\
\text { tural }\end{array}$ & $\begin{array}{l}\text { Pengaruh } \\
\text { Langsung }\end{array}$ & Pengaruh Tidak Langsung & Total Pengaruh \\
\hline $\begin{array}{l}\text { Pelayanan - Prefe- } \\
\text { rensi }\end{array}$ & 0,33 & - & 0,33 \\
\hline $\begin{array}{l}\text { Promosi - prefer- } \\
\text { ensi }\end{array}$ & 0,14 & - & 0,14 \\
\hline Lokasi - Preferensi & 0,26 & - & 0,26 \\
\hline $\begin{array}{l}\text { Pelayanan - Kepu- } \\
\text { tusan }\end{array}$ & 0,227 & $0,33^{*} 0,31=0,1023$ & 0,33 \\
\hline $\begin{array}{l}\text { Promosi - keputu- } \\
\text { san }\end{array}$ & 0,0766 & $0,14^{*} 0,31=0,0434$ & 0,12 \\
\hline Lokasi - Keputusan & 0,079 & $0,26 * 0,31=0,0806$ & 0,16 \\
\hline $\begin{array}{l}\text { Preferensi- Kepu- } \\
\text { tusan }\end{array}$ & 0,31 & - & 0,31 \\
\hline
\end{tabular}

\section{PENGUJIAN HIPOTESIS}

Pengujian hipotesis apakah ditolak atau diterima, maka merujuk kepada dasar pengambilan keputusan sebagai berikut:

Untuk pembahasan ini dapat dilihat pada pola dan hasil dari Structural Equationsdi atas.Maka, kesimpulannya sebagai berikut:

Tabel 7

Hasil Hipotesis

\begin{tabular}{|c|c|c|c|}
\hline tNo. & Hipotesis & Kesimpulan & Keterangan \\
\hline 1 & $\begin{array}{l}\text { H1: } \\
\text { "Persepsi Pelayanan, } \\
\text { Promosi dan Lokasi } \\
\text { secara simultan berpen- } \\
\text { garuh signifikan terha- } \\
\text { dap Preferensi Muzaki” }\end{array}$ & Ditolak & $\begin{array}{l}\text { Dari } 3 \text { Variabel Eksogen (Persepsi } \\
\text { Pelayanan, Promosi dan Lokasi), } \\
\text { terdapat } 1 \text { Variabel (Promosi) } \\
\text { yang tidak berpengaruh secara } \\
\text { signifikan. (Dapat dilihat pada } \\
\text { kolom dibawah) }\end{array}$ \\
\hline
\end{tabular}


Satria, Saparuddin, Mustafa: Lembaga Amil Zakat

\begin{tabular}{|c|c|c|c|}
\hline 2 & $\begin{array}{l}\mathrm{H} 2 \text { : } \\
\text { "Persepsi Pelayanan se- } \\
\text { cara parsial berpengaruh } \\
\text { signifikan terhadap Pref- } \\
\text { erensi Muzaki” }\end{array}$ & Diterima & $\begin{array}{l}\text { t-hitung }>\text { t-tabel } \\
(4,13>1,9 t 5)\end{array}$ \\
\hline 3 & $\begin{array}{l}\text { H3: } \\
\text { "Persepsi Promosi se- } \\
\text { cara parsial berpengaruh } \\
\text { signifikan terhadap Pref- } \\
\text { erensi Muzaki” }\end{array}$ & Ditolak & $\begin{array}{l}\text { t-hitung }<\text { t-tabel } \\
(1,44<1,95)\end{array}$ \\
\hline 4 & $\begin{array}{l}\text { H4: } \\
\text { "Persepsi Lokasi secara } \\
\text { parsial berpengaruh sig- } \\
\text { nifikan terhadap Prefer- } \\
\text { ensi Muzaki” }\end{array}$ & Diterima & $\begin{array}{l}\text { t-hitung }>\text { t-tabel } \\
(2,68>1,95)\end{array}$ \\
\hline 5 & $\begin{array}{l}\text { H5: } \\
\text { “Persepsi Pelayanan, } \\
\text { Promosi, Lokasi dan } \\
\text { Preferensi secara simul- } \\
\text { tan berpengaruh sig- } \\
\text { nifikan terhadap Keputu- } \\
\text { san Muzaki” }\end{array}$ & Ditolak & $\begin{array}{l}\text { Dari } 4 \text { Variabel Eksogen (Persepsi } \\
\text { Pelayanan, Promosi, Lokasi dan } \\
\text { Preferensi), terdapat } 2 \text { Varia- } \\
\text { bel (Promosi dan Lokasi) yang } \\
\text { tidak berpengaruh secara sig- } \\
\text { nifikan. (Dapat dilihat pada kolom } \\
\text { dibawah) }\end{array}$ \\
\hline 6 & $\begin{array}{l}\text { H6: } \\
\text { “Persepsi Pelayanan se- } \\
\text { cara parsial berpengaruh } \\
\text { signifikan terhadap } \\
\text { Keputusan Muzaki” } \\
\end{array}$ & Diterima & $\begin{array}{l}\text { t-hitung }>\text { t-tabel } \\
(2,59>1,95)\end{array}$ \\
\hline 7 & $\begin{array}{l}\text { H7: } \\
\text { "Persepsi Promosi se- } \\
\text { cara parsial berpengaruh } \\
\text { signifikan terhadap } \\
\text { Keputusan Muzaki” }\end{array}$ & Ditolak & $\begin{array}{l}\text { t-hitung }<\text { t-tabel } \\
(0,77<1,95)\end{array}$ \\
\hline 8 & $\begin{array}{l}\text { H8: } \\
\text { "Persepsi Lokasi secara } \\
\text { parsial berpengaruh sig- } \\
\text { nifikan terhadap Keputu- } \\
\text { san Muzaki” }\end{array}$ & Ditolak & $\begin{array}{l}\text { t-hitung }<\text { t-tabel } \\
(0,73<1,95)\end{array}$ \\
\hline 9 & $\begin{array}{l}\text { H9: } \\
\text { "Preferensi secara par- } \\
\text { sial berpengaruh sig- } \\
\text { nifikan terhadap Keputu- } \\
\text { san Muzaki” }\end{array}$ & Diterima & $\begin{array}{l}\text { t-hitung }>\text { t-tabel } \\
(2,97>1,95)\end{array}$ \\
\hline
\end{tabular}


Dari tabel tersebut di atas dapat diketahui bahwa; Persepsi Pelayanan, Promosi dan Lokasi secara simultan,tidak kesemuanya berpengaruh signifikan terhadap Preferensi Muzaki. Dari beberapa varianbel tersebut hanya satu variabel yang tidak berpengaruh signifikan terhadap preferensi, yaitu variabel promosi. Sehingga hal ini mengakibatkan ditolaknya hipotesis pertama.

Hipotesis kedua dimana; persepsi pelayanan secara parsial berpengaruh signifikan terhadap preferensi muzaki, diterima sesuai dengan hasil dari perbandingan t-hitung dan t-tabel serta pengaruhnya signifikan terhadap preferensi. Untuk hipotesis ketiga bahwa; persepsi promosi secara parsial berpengaruh signifikan terhadap preferensi muzaki, ditolak karena nilai t-tabel lebih besar dari t-hitung. Kemudian hipotesis keempat;persepsi lokasi secara parsial berpengaruh signifikan terhadap preferensi muzaki, diterima karena lebih besar t-hitung dari t-tabel seperti diketahui pada tabel di atas, dan pengaruhnya signifikan terhadap preferensi muzaki.

Persepsi pelayanan, promosi, lokasi dan preferensi secara simultan berpengaruh signifikan terhadap keputusan muzaki, untuk hipotesis kelima ini ditolak dikarenakan ada variabel yang tidak signifikan pengaruhnya terhadap variabel keputusan. Variabel yang sigifikan pengaruhnya adalah variabel preferensi dan variabel persepsi pelayanan, sedangkan yang tidak signifikan dua variabel juga yaitu variabel promosi dan variabel lokasi.

Untuk hipotesis keenam bahwa;persepsi pelayanan secara parsial berpengaruh signifikan terhadap keputusan muzaki diterima, kemudian hipotesis ketujuh;persepsi promosi secara parsial berpengaruh signifikan terhadap keputusan muzaki ditolak. Lalu hipotesis yang kedelapan; persepsi lokasi secara parsial berpengaruh signifikan terhadap keputusan muzaki, ini juga ditolak. Dan hipotesis kesembilan bahwa; preferensi secara parsial berpengaruh signifikan terhadap keputusan muzaki, diterima. Hal tersebut kesemuanya terlihat pada tabel di atas yang membahas tentang hipotesis.

\section{UJI APRIORI}

Pada hasil penelitian ini menunjukkan bahwa variabel pelayanan berpengaruh terhadap variable preferensi dengan besarnya pengaruh sebesar 0,33 pengaruh tersebut signifikan. Hal tersebut sejalan dengan penelitian yang dilakukan oleh Diana Puspitasari (2006), dan penelitian yang dilakukan Yaumil Fauza (2013) dimana persepsi pelayanan yang kemudian menjadi kepuasan pelanggan berpengaruh positif terhadap minat beli ulang atau bisa dikatakan menjadi preferensi yang kemudian mengarah kepada keputusan menggunakan atau membeli produk. Sedangkan variable promosi dalam penelitian ini tidak berpengaruh secara signifikan hal ini tidak sejalan dengan 
penelitian yang dilakukan oleh Alivinda, dkk (2014), dan juga penelitian yang dilakukan oleh Januar Arif, dkk (2014), dimana dalam penelitiannya diuraikan bahwa promosi berpengaruh terhadap preferensi konsumen. Untuk variabel lokasi mempunyai pengaruh yang signifikan terhadap variable preferensi hal ini sejalan dengan penelitian yang dilakukan oleh Lisna Netty Herawati (2011) dimana lokasi menjadi penentu preferensi begitu juga pada penelitian yang dilakukan oleh Januar Arif, dkk (2014) yang menguraikan bahwa variabel akses lokasi berpengaruh terhadap preferensi.

Di dalam penelitian ini dari 3 (tiga) Variabel yaitu variabel pelayanan, promosi dan lokasi terdapat 2 (dua) variabel; variabel pelayanan dan variabel lokasi yang berpengaruh signifikan dan yang 1 (satu) variabel; variabel promosi hanya berpengaruh secara parsial terhadap variabel preferensi. Dari sini dapat diketahui bahwa hanya persepsi tertentu saja yang bisa mempengaruhi preferensi muzaki dalam memilih Lembaga Amil Zakat, khususnya persepsi terhadap pelayanan dan lokasi. Hal ini sangat sejalana dengan penelitian yang dilakukan Lisna Nety Herawati yang menyimpulkan bahwa yang menjadi preferensi muzaki dalam memilih anatara LAZ dan BAZ adalah faktor lokasi dan pelayanan.

Hasil dari persamaan struktural kedua menunjukkan bahwa preferensi berpengaruh terhadap keputusan dengan besarnya pengaruh sebesar 0,31, begitu juga dengan variabel pelayanan mempunyai pengaruh signifikan terhadap variable keputusan dengan besarnya pengaruh sebesar 0,23. Hal ini sesuai dan sejalan dengan penelitian yang dilakukan oleh Widya Wardhani, dkk.(2015), dimana pada penelitian tersebut preferensi dan termasuk pelayanan memepunyai pengaruh signifikan terhadap keputusan pembelian. Sedangkan variable promosi dan lokasi tidak signifikan berpengaruh terhadap keputusan. Hal ini berbeda dengan penelitian sebelumnya yang dilakukan oleh Januar Arif, dkk.(2014), dimana promosi dalam penelitiannya berpengaruh signifikan pada pembelian produk/jasa.

\section{PENUTUP}

\section{KESIMPULAN}

Persepsi terhadap pelayanan, promosi dan lokasi berpengaruh terhadap preferensi muzaki dalammemilih Lembaga Amil Zakat.Yang paling berpengaruh terhadap preferensi adalah persepsi pelayanan dan lokasi yang dalam penelitian ini sangat signifikan pengaruhnya. Khusus untuk promosi sangat sedikit pengaruhnya terhadap preferensi dan pengaruh tersebut tidak signifikan. Persepsi pelayanan, promosi dan lokasi mempengaruhi variabel preferensi sebesar 35\%secara keseluruhan, sedangkan sisanya sebesar $65 \%$ dipengaruhi oleh variabel lain yang tidak dilibatkan dalam penelitian ini. 
Kemudian Keputusan muzaki dalam memilih dimana harus membayar zakat jika dilihat dari preferensi, persepsi pelayanan, promosi dan lokasi maka yang paling berpengaruh adalah preferensi dan persepsi pelayanan sedangkan lokasidan promosi tidak berpengaruh secara signifikan. Dan secara keseluruhan termasuk di dalamnya preferensi, pelayanan, promosi dan lokasi mempengaruhi variabel keputusan sebesar $32 \%$, sedangkan sisanya sebesar $68 \%$ dipengaruhi oleh variabel lain diluar dari keempat variabel tersebut. 


\section{DAFTAR PUSTAKA}

Antara News, “Baznas Diimbau Bangun Kepercayaan Pemberi Zakat”, Tanggal 7 Agustus 2013

Baznas Sumut, “Kebangkitan Zakat”, Edisi Khusus Idul Adha dalam Risalah Zakat, 2016.

Baznas Sumut, "Pertemuan Sinergi Bersama LAZ-LAZ yang ada di Sumut", dalam Risalah Zakat, Tanggal 24Mei 2016.

Bilondatu, Machrani Rinandha, "Motivasi, Persepsi, Dan Kepercayaan Pengaruhnya Terhadap Keputusan Pembelian Konsumen Pada Sepeda Motor Yamaha Di Minahasa", dalam Jurnal EMBA Vol.1 No.3 September 2013.

Budiman, Januar Arif, et.al., “Analisis Preferensi Konsumen Terhadap Keputusan Pembelian Madu Di Kota Blitar”, dalam Jurnal Administrasi Bisnis, Malang, 2014.

Farizi, Muhammad Iqbal, Kepala Cabang IZI Sumatera Utara, wawancara di Medan, tanggal 25 Agustus 2016.

Fauza, Yaumil, “Analisis Preferensi Masyarakat Dalam Memilih Institusi Pembayaran Zakat Di Kota Medan”, (Skripsi, Fakultas Ekonomi USU, 2013).

Fedira, Alivinda Difa, et. al., “Analisis Faktor Yang Mempengaruhi Preferensi Konsumen Terhadap Kopi Susu Instan Di Kota Malang Menggunakan Metode Partial Least Square (PLS)", dalam Jurnal Lulusan TIP FTP UB, Malang, 2014.

Harahap, Mila Nova, Staf LAZ Rumah Zakat Sumatera Utara, wawancara di Medan, tanggal 25 Agustus 2016.

Herawati, Lisna Nety, Preferensi dan Keputusan Masyarakat Kecamatan Karawaci Dalam Menyalurkan Zakat," (Skripsi, UIN Syarif Hidayatullah Jakarta, 2011)

http://www.dompetdhuafa.org/page/katalog\%2oprogram/. (Diakses tanggal 25 Nopember 2016)

http://www.pajak.go.id/content/122211-daftar-lembaga-keagamaan-yang-disahkan. (Diakses tanggal 17 September 2016).

https://izi.or.id/\#. (Diakses tanggal 25 Nopember 2016).

https://www.rumahzakat.org/\#. (Diakses tanggal 25 Nopember 2016)

Kotler, Philip dan Gary Armstrong, Prinsip-prinsip Pemasaran, Edisi 12, Jilid 2, Jakarta: Erlangga, 2008.

Laksana, Fajar, ManajemenPemasaran: Pendekatan praktis, Yogyakarta: Graha Ilmu, 2008. 
Lupiyoadi, Rambat, et. al., Manajemen Pemasaran Jasa, Jakarta: Salemba Empat, 2008

Nasution, Juliana, Staff Keuangan LAZ Dompet Dhuafa Waspada, wawancara di Medan, tanggal 7 September 2016.

Puspitasari, Diana, “Analisis Pengarus Persepsi Kualitas Dan Kepuasan Pelanggan Terhadap Minat Beli Ulang (Studi Kasus pada Maskapai Penerbangan Garuda Keberangkatan Semarang)," (Tesis, Pascasarjana UNDIP Semarang, 2006).

Republika,"Potensi Zakat Nasional Mencapai Rp 217 Triliun", Tanggal 21 Januari 2016.

Rescoe, J.T., Fundamental Research Statistics For The Behavioral Sciences, $2^{\text {nd }}$ edition., (New York: Holt Rinehart \& Winston, 1975).

Saladin, Djaslim, Unsur-Unsur Inti Pemasaran dan Manajemen Pemasaran, Bandung: Mandar Maju, 2004.

Saladin, Djasmin dan Yevis Marty Oesman, Intisari Pemasaran dan Unsur-Unsur Pemasaran, Bandung: Linda Karya, 2002.

Simamora, Bilson, Panduan Riset Perilaku Konsumen, Jakarta: PT. Gramedia Pustaka Utama, 2003.

Sutisna, Perilaku Konsumen dan Komunikasi Pemasaran, Bandung: PT Remaja Rosdakarya, 2001.

Swastha, Basu dan Ibnu Sukotjo, Pengantar Bisnis, Yogyakarta: Liberty, 2010.

Trianto, Budi. Riset Modeling. Pekanbaru: Adh-Dhuha Institute, 2016.

Wardhani, Widya, et. Al., "Pengaruh Persepsi dan Preferensi Konsumen Terhadap Keputusan Pembelian Hunian Green Product ", dalam Jurnal Manajemen dan Organisasi, Vol VI, No 1, April 2015.

Undang-Undang Nomor 23 Tahun 2011 Tentang Pengelolaan Zaka

Undang-Undang Nomor 38 Tahun 1999 Tentang Pengelolaan Zakat. 